\title{
RANCANGAN APLIKASI “TEGAR” PENDETEKSI TEMPE SEGAR
}

\author{
ANGGA ADITYA PERMANA ${ }^{1)}$, RIFQI RIADHI ${ }^{2}$, DESI NURNANINGSIH ${ }^{3)}$ \\ RACHMAT DESTRIANA ${ }^{4)}$ \\ 1,2,3,4) Program Studi Teknik Informatika \\ Fakultas Teknik Universitas Muhammadiyah Tangerang \\ Jl. Perintis Kemerdekaan I/33, Cikokol Kota Tangerang \\ Email:anggaumt@gmail.com
}

\begin{abstract}
ABSTRAK
Tempe sebagai salah satu makanan khas Indonesia Indonesia sudah menjadi bagian yang tak terpisahkan dari pola makan sehari-hari. Kesegaran tempe menjadi salah satu indikator penilaian kualitas tempe, karena masa simpan tempe yang tergolong singkat. Penyimpanan tempe pada suhu ruang memungkinkan terjadinya pertumbuhan bakteri dan perubahan struktur kimia dari makanan. Deteksi tingkat kesegaran tempe masih dilakukan secara manual menggunakan indera penglihatan. Teknologi penentuan tempe segar berbasis dekstop membantu diagnosis, pemantauan serta analisis makanan terutama tempe. Perancangan aplikasi "TEGAR" penentu tempe segar dilakukan dalam beberapa tahap meliputi pengambilan data dan pengembangan sistem berdasarkan implementasi image processing dan machine learning untuk mendeteksi tingkat kesegaran dan kualitas tempe.
\end{abstract}

\section{Kata Kunci: Kesegaran, Pengolahan Citra Digital, Tempe.}

\section{PENDAHULUAN}

Tempe merupakan produk turunan kedelai yang dibuat melalui fermentasi menggunakan ragi tempe berupa kultur campuran Rhizopus spp. Sebagai salah satu makanan khas Indonesia, tempe sudah menjadi bagian dari pola makan masyarakat sehari-hari. Tempe segar umumnya hanya bertahan 1-2 hari jika disimpan pada suhu ruang, kemudian akan terjadi perubahan fisik, kimia dan sen- soris sehingga kesegaran tempe tersebut mengalami penurunan. Kesegaran tempe se- bagai salah satu sumber protein utama masyarakat menjadi indikator penting penentu berkualitas atau tidaknya tempe. Kesegaran makanan yang dikonsumsi secara langsung maupun tidak langsung akan mempengaruhi kesehatan konsumen (Shahzad et al. 2018).

Tempe yang akan dikonsumsi dipilih secara kasat mata oleh konsumen tanpa diketahui apakah tempe tersebut masih segar (berkualitas baik) atau tidak. Metode penentuan secara manual ini memiliki beberapa keterbatasan serta hasil yang tidak konsisten karena pengamatan bersifat subjektif tergantung dari masing-masing konsumen. Oleh karena itu, aplikasi yang dapat menentukan kesegaran tempe secara otomatis dan realtime perlu untuk dikembangkan.

Pengembangan aplikasi penentu tempe segar dilakukan berdasarkan pengolahan citra digital. Pengolahan citra digital mampu mengenali kondisi fisik objek dengan lebih peka, karena dilengkapi dengan sensor elektro-optik yang lebih tepat dan objektif (BB Pascapanen 2009). Beberapa bahan makanan dapat ditentukan kualitasnya melalui pengolahan citra digital, seperti ukuran telur (Sidiq \& Irmawati 2016), tingkat kesegaran ikan (Bee et al. 2016), kesegaran daging (Arsy et al. 2016) serta jenis dan mutu teh (Effendi et al. 2017).

Aplikasi penentu kesegaran tempe "TEGAR" akan mempermudah konsumen menentukan segar atau tidaknya tempe yang akan dikonsumsi. Aplikasi "TEGAR" memungkinkan konsumen mengambil gambar tempe, melakukan proses pengolahan gambar serta mendapatkan hasilnya secara realtime. Gambar tersebut dianalisis berdasarkan implementasi image processing dan machine learning untuk mendeteksi tingkat kesegaran 
dan kualitas tempe.

\section{METODE PENELITIAN}

Penelitian ini dilakukan di Laboratorium Komputer, Fakultas teknik, Universitas Muhammadiyah Tangerang. Tahapan penelitian diawali dengan pengambilan data sampel dan dilanjutkan dengan perancangan aplikasi dekstop "TEGAR" penentu tempe segar. Sampel tempe diambil dari kampung tempe kel koang jaya kec karawaci sebanyak tiga kali pengulangan, kemudian hasilnya dianalisis lalu kemudian dijadikan bahan untuk membuat aplikasi. Aplikasi ini berbasis Matlab yang dapat menentukan kesegaran tempe menggunakan ekstraksi fitur warna Red Green Blue (RGB). Aplikasi yang dihasilkan masih dalam versi desktop.

Langkah-langkah untuk merancang aplikasi penentu kesegaran tempe, yaitu read image data, resize, define object, select object, crop origin image with selected object, compare images and define image status. Data diambil menggunakan smartphone dan program dibuat menggunakan laptop. Gambar tempe yang telah diambil menggunakan smartphone akan langsung masuk ke dalam sistem, selanjutnya sistem akan memproses citra sama seperti saat pengambilan data sampel. Setelah itu sistem akan membandingkan nilai data citra digital dengan parameter citra yang telah diperoleh, kemudian mengklasifikasikan citra tersebut secara otomatis ke dalam golongan segar (berkualitas baik) atau tidak segar (berkualitas buruk).

\section{HASIL PENELITIAN}

Kesegaran tempe merupakan salah satu indikator penting dalam penentuan kualitas tempe itu sendiri. Berikut ini gambaran layout aplikasi "TEGAR" penentu tempe segar.

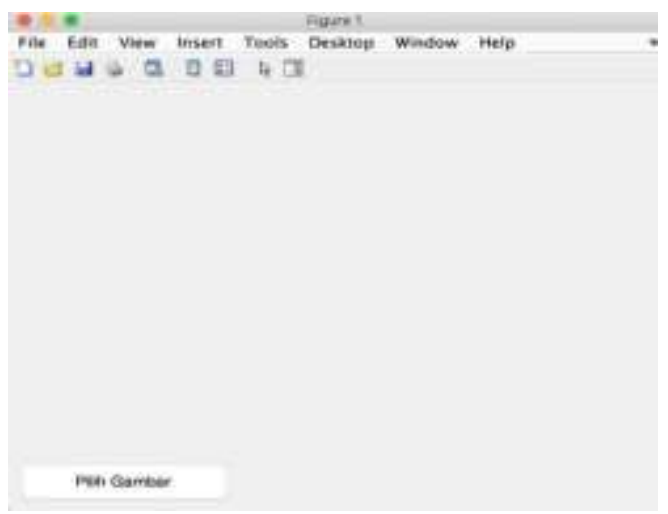

Gambar 1. Menu Utama

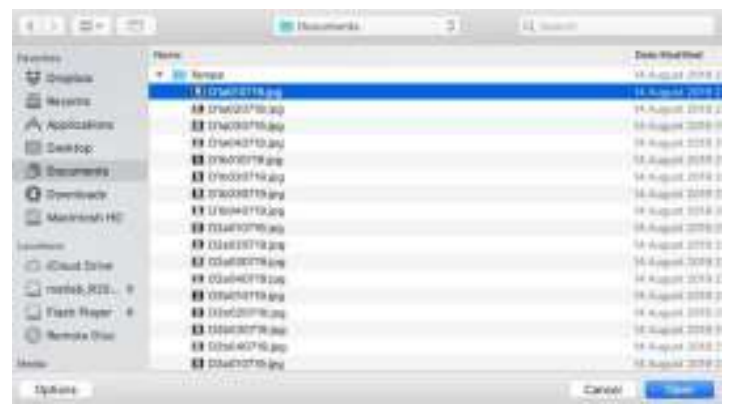

Gambar 2. Pilih File



Gambar 3. Setelah memilih File.

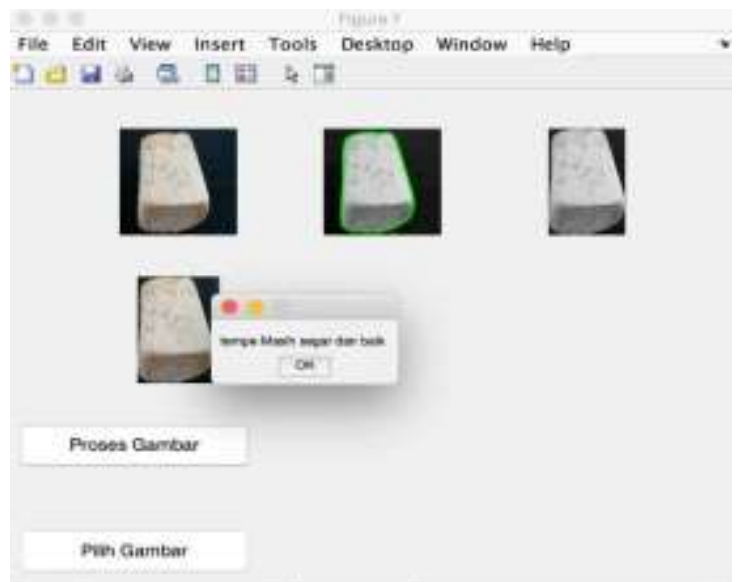

Gambar 4. Percobaan tempe baik.

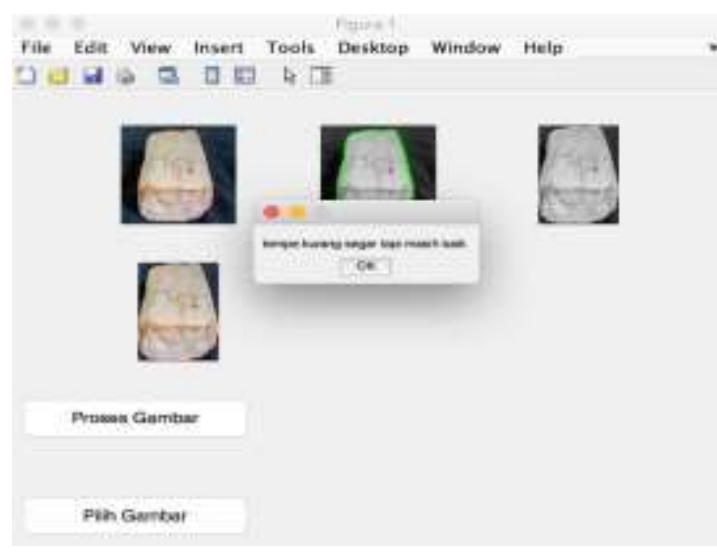

Gambar 5. Percobaan tempe Kurang baik. 


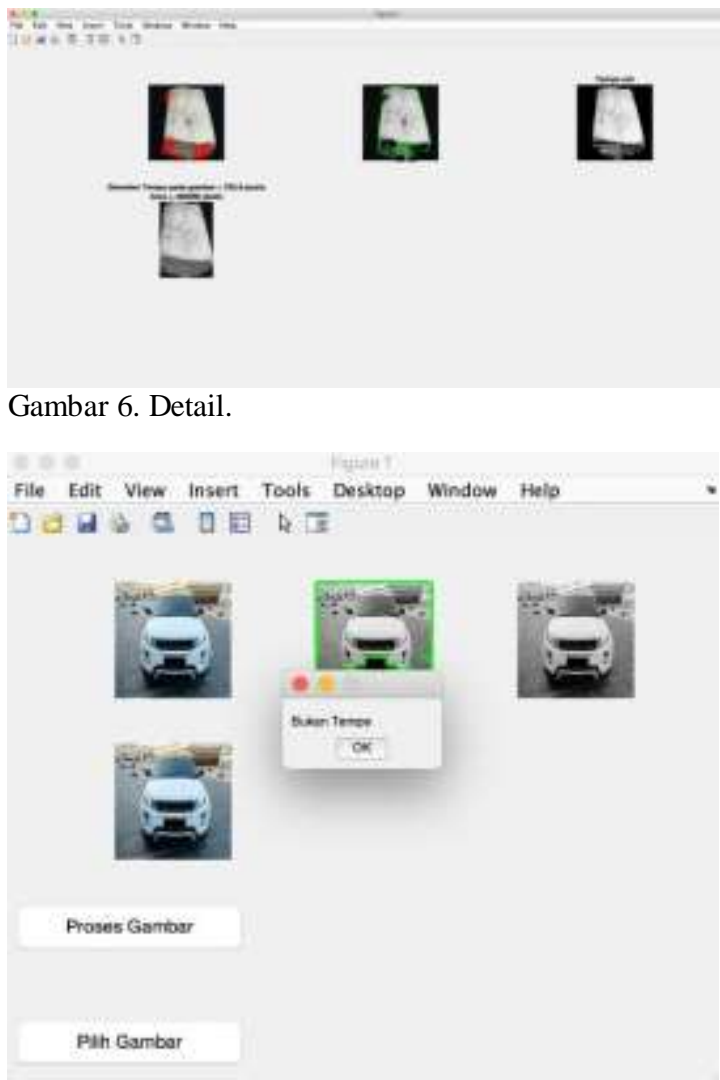

Gambar 7. Deteksi Gambar selain Tempe.

\section{KESIMPULAN}

Aplikasi "TEGAR" penentu tempe segar berhasil dirancang berbasis citra digital dan matlab.

\section{DAFTAR ISI}

Arsy, L., Nurhayati, O.D., Martono, K.T. Aplikasi pengolahan citra digital meat detection dengan metode segmentasi $\mathrm{k}$ mean clustering berbasis openCV dan eclipse. J Teknol Sis Kom. 4, (2016), 322-332.

[BB Pascapanen] Balai Besar Penelitian dan Pengembangan Pascapanen Pertanian. Mengidentifikasi mutu fisik jagung dengan memanfaatkan teknologi pengolahan citra digital. Warta Penelitian dan Pengembangan Pertanian. 5, (2009), 46.

Bee, D., Weku, W.C.D., Rindengan, A.J. Aplikasi penentuan tingkat kesegaran ikan selar berbasis citra digital dengan metode kuadrat terkecil. $J d C$. 2, (2016), 121-130.

Effendi, M., Fitriyah, Effendi, U. Identifikasi jenis dan mutu teh menggunakan pengolahan citra digital dengan metode jaringan syaraf tiruan. J Teknotan. 11, (2017), 67- 76.

Shahzad, N., Khalid, U., Iqbal, A., Ur Rahman, M. eFresh- a device to detect food freshness. Int J Soft Comp Engin. 8, (2018), 1-4.

Sidiq, S.A., Irmawati, D. Pengolahan citra untuk identifikasi telur berdasarkan ukuran. J Elec Infor Voc Edu. 1, (2016), 151-156. 